\title{
E-Communication During Covid-19 Outbreak: A Study Of Social Media As A Public Sphere In Jakarta
}

\author{
Luky Fitriani $^{1}$, Pawito $^{2}$, Prahastiwi Utari ${ }^{3}$ \\ ${ }^{1}$ Master of Communication Study Program, ${ }^{2,3}$ Department of Communication Science Universitas \\ Sebelas Maret, Surakarta Indonesia \\ ${ }^{1}$ lukyfitriany@gmail.com, ${ }^{2}$ pawito_palimin@staff.uns.ac.id, ${ }^{3}$ prahastiwi@staff.uns.ac.id
}

\begin{abstract}
Following the COVID-19 outbreak in Wuhan, the Republic of China has become a major concern in the world. Besides the massive spreading information around many countries, including Indonesia, the information related to COVID-19 has also become an important issue both for the individual and also social media users. Social media has an important role in spreading the information and its associated analyses; as in January 2020, a CBS News correspondent Ramy Inocencio reported the COVID-19 case on his Twitter. The report became a big hit since many mainstream media and social media users around the world discussed it. In this respect Jürgen Habermas defines the public sphere as a discussion platform which allows individuals to express their opinions in public without interference. A qualitative approach is used in this research by taking the advantage of interviews as a data collection tool. It also captures that Instagram is the most frequently used by public of Jakarta to get information related to COVID-19. Meanwhile, Whatsapp is used to discuss and exchange information among them during outbreak. And the most frequently topic to be discussed are the number of COVID19 case update and its wide-spreading.
\end{abstract}

Keywords. COVID-19, social media, public sphere, the outbreak, e-communication

\section{Introduction}

The press has been known as a tool for disseminating information to the public, but unfortunately, it has only been one-way-flow for more than decades in Indonesia. Still, due to the technology transformation, media has an important role in the social changes by empowering the public sphere. So as the mass media audience could give feedback related to the information they are concerned for. Many scholars have agreed that media acts as a really big role in shaping our ideas and establishing our position in society. However, according to German Scholar, Jürgen Habermas in his book, The Structural Transformation of Public Sphere, he stated that the media have turned into deceiver tools by turning the public into passive consuming audience since the state, corporates and media control the public sphere [1]. Moreover, according to Habermas, the public sphere must involve the community in every discourse without the existence of certain structures or limitations [2].

As technology develops, the mass media is also experiencing a dramatic change. For example; a newspaper in the United Kingdom expands its function by adding columns of comments, opinions, criticism in addition to create interaction among the readers. It means that the developments of the internet facilitate the existence of the digital public sphere nowadays [1]. This has become a separate space for discussion between the bourgeoisie and 
the intelligence community. Eventually, social media was formed as the latest product of the communication technology revolution. The public sphere and public opinion are two very strong terms related to the function of the media and the representative theory of democracy [3].

The internet in the field of communication gives rise to many new products in the form of social space, including social media. Social media is classified as a new media which is different from conventional media such as; TV, newspapers and radio. When initially the mass media only went in one direction flow, on the contrary, social media enabled the public to interact and exchange information and opinions among them or media itself. These discourse areas are referred to as a public sphere by Habermas. Following Habermas, the public sphere is a social area where public opinion can be formed without the presence of limitation or exclusion boundaries. Concerning COVID-19 pandemic, we can see that the role of social media is very important. Twitter was one of the early platforms which spread the first case of COVID-19 news in Wuhan by CBS correspondents who served in Hubei Province at the middle of last January. Interestingly from Twitter, the news regarding COVID-19 became widespread in the world. This phenomenon shows how strong and massive social media role that was driven by the public, to form opinions and also spreading its information.

Therefore by this research, the author wants to focus on how social media has played a role as a public sphere for the public of Jakarta to form and exchange opinions during the COVID19 outbreak.

\section{Method}

The research was using qualitative methods and interview as the data collection tool. The selected informants were those who live and work in Jakarta. Jakarta as the capital of Indonesia was chosen as a place of the research as it is the central area of the spread of the Coronavirus or the epicentre spot with the largest number of infected people in Indonesia. And its citizens are the highest active users of social media compared to other areas.

The interviews produced 23 answers. They were chosen by purposive sampling method since the researcher has determined the characteristics and knew the right informants who met the specified criteria. The current number of informants were produced by the onlineinterview. Since it was conducted by Google form service which can be open-accessed by everyone through its link and some of them were followed up by direct-interview based on the result of the prior interview. This follows up was done for gaining more in-depth information. Due to pandemic and physical distancing, consequently, the collecting data must be organized via online platforms. This research was conducted about three months since last May to July 2020 .

\section{Result and Discussion}

Since Since the innovation of the internet, the scholars brought the idea of differentiation of the public sphere and public opinion from their classical meaning to a new "networked 
public sphere" where the public opinion is shaped through exchanges in online platforms [1]. This new formed of the public sphere has reached a higher level thanks to social media platforms like Facebook, Twitter and YouTube. These users can communicate freely with each other and consequently can come together for a certain theme. Communicating online means to publish online which on the other hand refer to be connected online with other people. The published content in social media is reachable from anyone throughout the world. This way is eliminating physical and infrastructure obstacles. As a consequence, the public find it easier to gather and express themselves [4].

This study produced 23 responses from the key informants, therefore based on the results of the interview, the social media are used by the public of Jakarta to get and exchange the information regarding COVID-19; 1. Instagram, 2. Twitter, 3. Whatsapp, 4. YouTube and 5. Facebook.

Each of those social media has its characters which successfully attract the informants. Instagram is the most frequently used since it has a video and infographic feature so easy to understand by its audience. Moreover, all media organizations, both national and international have an Instagram account as well. Therefore it was reachable by following their Instagram account and keep up the update regarding the COVID-19 issue. For example, international media organizations such as $\mathrm{ABC}, \mathrm{CBS}$, VOA, and BBC post the COVID-19 content update regularly. The Indonesian local news organizations are using the Instagram account as well to give the updated pieces of information; Tempo, Kompas, The Jakarta Post and so on.

There are other reasons to support why Jakarta's public prefer Instagram rather than other social media. Aulia Kurnia Hakim, a TV journalist in Jakarta said that she regularly accessed the Instagram to look for public transportation operational info during COVID-19 outbreak. Meanwhile Erny Suciapriyanti, a private employee choose Instagram as her favourite media social since its easy and used to access it long before the outbreak. Some informants also agree that Instagram has full-visual-package information related to COVID-19. The infographic becomes its attraction and most popular among the informants. The data shows there are some other reasons to support this:

a. All news organizations publish their information regarding COVID-19 on Instagram as a daily service.

b. Video, illustration and animation or any other creative form involvement in its content become a consideration to access.

However, some other informants prefer Twitter as a source of COVID-19 information. To support this, we must be remembered to the point when the first case of COVID-19 burst out in the public at the last January. The early case information of COVID-19 spread by a CBS journalist at the midst of January. Then it became popular and quoted by many users around the world. In addition, it turned out to be a trending topic in the world. However long before the pandemic era, Twitter was already popular for its advantage as a media platform. Many pieces of information could be found via Twitter.

Dani Purba as one of Twitter user said: "For me, Twitter is a kind of early media, we know all the new information, including breaking news. Since all of the news organizations, particularly online news company will upload their news on Twitter. It includes news about COVID-19 as well. So besides getting an expert perspective reviewed in the news, I also know the public perspective on that issue thru Twitter. On Twitter, the public is given extensive opinion space through words, so I know every reaction of them to a particular issue. A recent 
example is how netizen (internet citizen) responded to a clinical trial plan for the coronavirus vaccine made by Sinovac, a Chinese company in Indonesia."

Furthermore, there are other reasons why some users tend to more enjoy Twitter, such as: a. Accessible.

b. Fast pace update information.

c. Informative and interactive (two-step flow communications).

At the same time, a-32years-old-male-informant, Johanes Ginting chooses Whatsapp as a discussion platform to exchange the information with his colleagues in a group. Johanes said that he prefers Whatsapp since the member of his Whatsapp Group frequently share the information regarding the update of COVID-19.

Rotua Nuraini Tampubolon has a different opinion. She frequently used Facebook to gain the COVID-19 update. She said that Facebook has more feature for video and long-writing information. So she can read it thoroughly.

The presence of this new form of the public sphere through social media is successfully arousing the free and unlimited topic to discuss with. There are many topics and agenda that mostly discuss by the public of Jakarta regarding COVID-19, such as; 1. COVID-19 confirm case update including death rate and its spreading in Indonesia, 2. Indonesian government policy on the development of COVID-19 outbreak, 3. Pros and contras regarding COVID-19 issue, 4. Misinformation and hoax related to COVID-19, 5. Vaccine trial and development against COVID-19, 6. World development against COVID-19.

As an example, Inge Klara, the Indonesian printed-journalist and Khumaesa Lissa, a medical doctor agree that the most frequently topic to be discussed regarding COVID-19 were case update, the misinformation and hoax. They said that recently many controversial issues have been disturbing their mind. As they are a journalist and doctor who have an important role during this pandemic.

The latest controversy has been done by Anji, an Indonesian-singer-influencer which uploaded a video interview on his YouTube channel. The video showed a figure who claimed has found a herb medicine for COVID-19. This issue became controversy for several days and trending among the public as well.

Khumaesa Lissa has this concern as she is a doctor. She thought that misinformation and hoax have a big impact to give a bad influence on people with middle-low education. She regularly found people in her Whatsapp Group shared hoax news before confirming it first. She was really annoyed by that. Not only Khumaesa Lissa, but Inge Klara also felt anxious by these matters.

Therefore the only thing that can be done by them was trying to participate and educate people around them by showing what should they do before consuming the information. Khumaesa Lisa take the part as a doctor by share the proper medical journal in her Whatsapp Group to busting the hoax. And Inge Klara did reshare her piece of news regarding the hoax on her Instagram as a journalist. Both of them has their own way to express their opinion as an individual.

Still according to Habermas, back in the early eighteen century when Great Britain had about three thousand salons, coffee and tea shops. The community who be able joined the public sphere were a group of British aristocrats, and the coffee shop itself not only provides access to relevant circles but also to a broader middle class, including craftsmen and shop staff. 
However, women in Britain could not join the coffee shop community, in consequence, they had to put up violent and painful resistance to this new institution. As they will be left by the men to the coffee shop every evening. Whereas only men are allowed to enter the coffee shop community [2].

Apart from criticisms about the exclusion of women in the public sphere by Habermas, other criticisms have also emerged, such as the exclusivity of this public sphere. Habermas's public sphere is considered an elite concept that does not involve representative components from the lowest level of society [1].

Many previous studies on the public sphere can be used as a comparison and the test result. The research by Ari Adut for instance, on his paper "A Theory of the Public Sphere", he quoted the Calhoun (1992) statement about identities are excluded by Habermas's theory. He argued that public sphere often formed in the course of public debates, as feminists have pointed about gendered nature of private and public distinction and to female forms of public action (Elshtain 1981; Pateman 1983; Ryan 1990) [5].

In contrary to the result of this study, most of the informants are women. Among 23 key informants, it consists of 18 women and 5 men interviewees. It means that the new era of the public sphere gives more freedom space for women involvement too. Inge Klara and Khumaesa Lissa for instance. They participated in the networked public sphere by taking advantage of social media. By this they did get information, share and exchange their ideations and opinion in the public sphere.

\section{Conclusion}

Based on the data and analysis presented before it could be concluded that, firstly, Instagram is found as the most frequently used by the public in Jakarta by its visual information as the advantages. Subsequently, Twitter is the second most frequently used to get COVID-19 information and lastly Facebook. However, some of the informants prefer Whatsapp as social media to share, express and exchange their opinions regarding COVID-19 issue.

Secondly, it could be stipulated that the confirm case update of COVID-19 in Indonesia and its government policy against COVID-19 outbreak are the major topic or agenda to be discussed by the public in Jakarta. In this respect, the government policies which are commonly discussed are the COVID-19 update and vaccine trial on the public. Besides, the spreading of misinformation and hoax are also a popular topic to be discussed by the public of Jakarta recently. This occurs based on the escalation of news in Indonesia.

The recent networked public sphere has involved women in the community to participate. This phenomenon is contrary to the concept of the public sphere in the 18th century.

\section{References}

[1] E. Cela.: Social Media as a New Form of Public Sphere. European Journal of Social Sciences and Education Research. Vol. 4, No. 1. pp. 195-200. (2015) 
[2] J. Habermas.: Ruang Publik: Sebuah Kajian Tentang Kategori Masyarakat Borjuis, terj. Yudi Santoso. Kreasi Wacana, Bantul (1991)

[3] B. Mecnair, Introduction into politic communication. Tirana: Uet-Press, (2009)

[4] C. Fuchs,: Social Media, A critical introduction. Sage Publication, London (2014)

[5] A. Adut,: A Theory of Public Sphere. Sociological Theory. University of Texas. Researchgate, Austin (2012) 